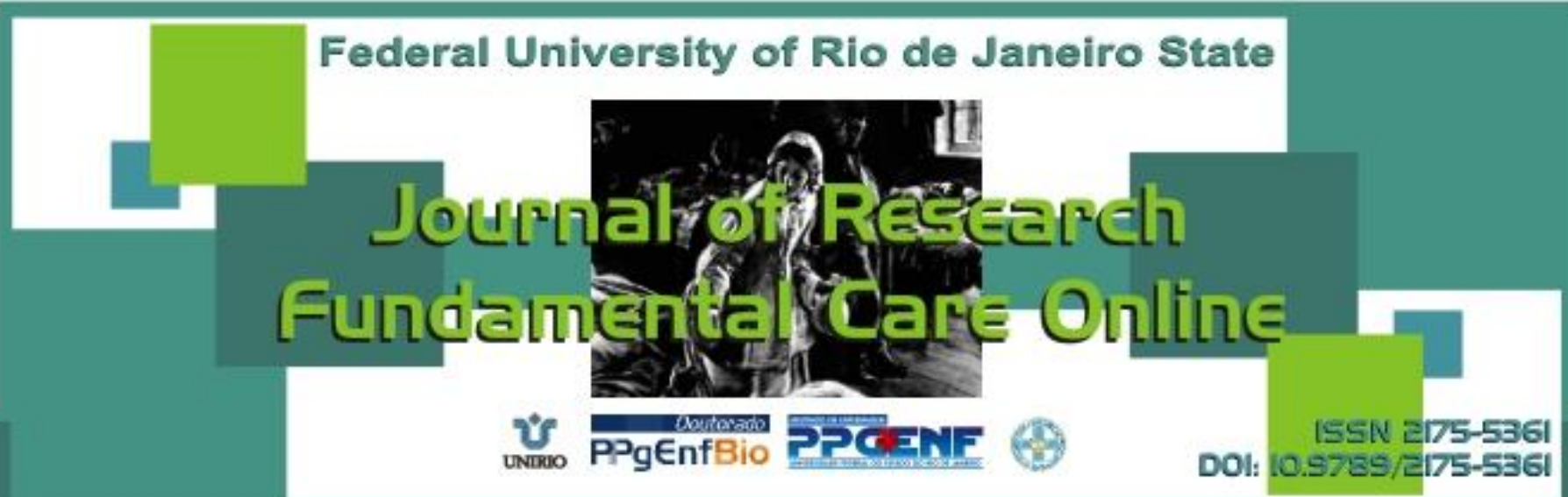

\title{
RESEARCH
}

\section{A group dynamic as a strategy for teaching-learning in a nursing management course}

A dinâmica de grupo como estratégia de ensino-aprendizagem na disciplina de gerenciamento de enfermagem

La dinamica de grupo como una estrategia de enseñanza-aprendizaje en la disciplina de gestión de enfermería

Geilsa Soraia Cavalcanti Valente ${ }^{1}$, Natasha Otero Fernandes ${ }^{2}$, André Luiz de Souza Braga ${ }^{3}$, Deise de Souza Ferreira ${ }^{4}$

ABSTRACT

Objective: To describe and evaluate the participation of academics and identify their perception about the importance of group dynamics for learning Nursing Management. Method: A qualitative and exploratory approach. The data were collected in the School of Nursing of the Federal Fluminense University, through a questionnaire. The subjects are 31 academicians of the 6th period, in the discipline of Management in Health Care I, in the second half of 2011, after approval by the Ethics Committee of the Faculty of Medicine of the same university, under N. 162/11. Results: Three thematic categories: Group dynamics as a strategy for teamwork, as an interaction strategy and as a teaching-learning strategy. Conclusion: The dynamics contributed to the team work as well as to the interaction with the teachers, for the understanding the discipline taught, reflecting the importance of this strategy in nursing education. Descriptors: Group processes, Management, Nursing, Teaching.

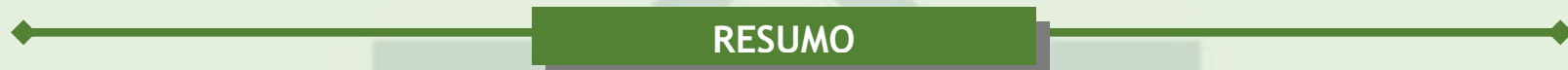

Objetivo: Descrever e avaliar a participação dos acadêmicos e identificar a percepção dos mesmos quanto à importância da dinâmica de grupo para o aprendizado da gerência em Enfermagem. Método: Abordagem qualitativa e exploratória. Os dados foram coletados na Escola de Enfermagem da Universidade Federal Fluminense, por meio de questionário. Os sujeitos são 31 acadêmicos do $6^{\circ}$ período, que cursaram a disciplina Gerenciamento da Assistência em Saúde I, no segundo semestre de 2011, após aprovação pelo Comitê de Ética da Faculdade de Medicina da referida universidade, sob $n^{\circ} 162 / 11$. Resultados: Três categorias temáticas: A dinâmica de grupo como estratégia para o trabalho em equipe; como estratégia de interação e como estratégia de ensino-aprendizado. Conclusão: A dinâmica contribuiu tanto para o trabalho em equipe, quanto para a interação com os professores, bem como para o entendimento da disciplina ministrada, traduzindo a importância dessa estratégia na formação do enfermeiro. Descritores: Processos grupais, Gerência, Enfermagem, Ensino.

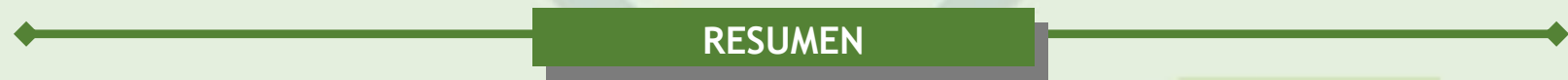

Objetivo: Describir y evaluar la participación de académicos e identificar su percepción de la importancia de la dinámica de grupo para el aprendizaje de la gestión de enfermería. Método: Enfoque cualitativo y exploratorio. Los datos fueron recolectados en la Escuela de Enfermería de la Universidad Federal Fluminense, a través de un cuestionario. Los sujetos son de 31 académicos del sexto semestre, en la disciplina de Gestión en Salud I, en el segundo semestre de 2011, tras su aprobación por el Comité de Ética de la Facultad de Medicina de la misma universidad, bajo $N^{\circ} 162 / 11$. Resultados: Tres categorías temáticas: dinámicas de grupo como estrategia de trabajo en equipo, como estrategia de interacción y como estrategia de enseñanza-aprendizaje. Conclusión: La dinámica contribuyó tanto al trabajo en equipo, la forma de interactuar con los profesores, así como para la comprensión de la materia de estudio, lo que refleja la importancia de esta estrategia en la educación de enfermería. Descriptores: Procesos de grupo, Gerencia, Manejo, Enfermería, Enseñanza.

${ }^{1}$ Nurse, Professor of Nursing at the School of Nursing Aurora Afonso Costa, Federal Fluminense University/UFF. Niterói (RJ), Brazil. E-mail: geilsavalente@yahoo.com.br. ${ }^{2}$ Nurse, School of Nursing Aurora Afonso Costa, Federal Fluminense University/UFF. Niterói (RJ), Brazil. E-mail: nattasha.fernandes@gmail.com. ${ }^{3}$ Nurse, Professor of Nursing at the School of Nursing Aurora Afonso Costa, Federal Fluminense University/UFF. Niterói (RJ), Brazil. E-mail: andre.braga@globo.com. ${ }^{4}$ Nurse, Professor of Nursing at the School of Nursing Aurora Afonso Costa, Federal Fluminense University/UFF. Niterói (RJ), Brazil. Email: dfsnit@hotmail.com. 


\section{INTRODUCTION}

his article is the result of the monitoring activities of the discipline of Management in Health Care I Course Undergraduate Nursing, Fluminense Federal University (UFF). To observe the progress of the discipline throughout the semesters, it was noted that there is a difficulty of students to articulate theory and practice, ie, to perceive the grip of theoretical with the reality of the daily work of nurses. Thinking about the possibility of contributing to minimize this difficulty, it was thought the use of group dynamics as a strategy for teaching and learning.

It is believed that a professional in leadership positions, such as nurses, must possess skills and competencies that are necessary for the running of the service and wellfunctioning team. For these features to be developed is first necessary to identify them. Group dynamics, among other things, facilitates this identification as the personal characteristics of the subjects are shown unconsciously, to the situations they are placed during the dynamics.

Group dynamics is a valuable educational tool that can be used to work teaching and learning when it is chosen to a conception of education that values both theory and practice and is considered all involved in this process as subjects. Allows the people involved to go through a process of teaching and learning where the collective work is placed as a way to interfere with reality and modifying it. This is because the experience of working with dynamic promotes meeting people where knowledge is built together in group. ${ }^{1}$

Nursing work is done in teams and their results are the fruit of an interpersonal relationship between the members that make up this team. For this relationship becomes satisfactory is important that each individual has primarily knowledge and mastery of your emotions and attitudes when faced with situations that arise in the workplace. From this premise, there is a need for a process of teaching and learning that goes beyond technical isolated but that is articulated to the development of the internal resources of the student as a human being.

The study of group dynamics is important for being appointed as a fact that signals the need for humans to seek to understand the movements present within groups, so as to contribute to the improvement and betterment of society. ${ }^{2}$ Upon learning of these movements, the possibility arises to grasp the limits and possibilities of working within groups so that you can enjoy these experiences in an active way. This means that it is possible to "live" the group is also possible to give, receive and exchange ideas and feelings. Living the group also means dealing with diversity, the lack of something done, with the possibility of conflict and confrontation, but also with the union and the creation. ${ }^{3}$

Based on the above, it has been an object of this study: Possibilities and difficulties in the implementation of group dynamics as a strategy for teaching and learning in the discipline of nursing management. From the problem into focus, drew up objectives: to 
identify the contributions of group dynamics in the teaching-learning during the academic discipline of nursing and manages in discussing the possibilities and difficulties of the use of group dynamics in the teaching-learning in the academic discipline of nursing manage.

\section{METHODOLOGY}

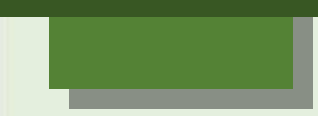

This is a descriptive study with a qualitative and exploratory. Both creativity performed by the researcher as the theoretical approach and techniques for the construction of reality composes instrumental own path and approach the theory of reality that lead to the methodology. ${ }^{4}$ Descriptive research aims to describe the characteristics of a given population and therefore involves the use of standard techniques of data collection, eg, survey and systematic observation. ${ }^{5}$

The qualitative approach aims to work with the universe of meanings, beliefs, values and attitudes corresponding to a deeper space of relationships, processes and phenomena that cannot be reduced to the operationalization of variables. She cares a level of reality that cannot be quantified. ${ }^{4}$

The subjects that make up the research are 31 students from the $6^{\text {th }}$ semester, in the discipline of Management in Health Care I, in the second half of the year 2011 of the Graduate Degree at the School of Nursing Aurora de Afonso Costa (EEAAC), Federal Fluminense University, after approval by the Ethics Committee of the Faculty of Medicine of the same university, under $n .162 / 11$.

Data were collected from the observation of the researchers during the course of the dynamics performed in the classroom and through a questionnaire with an open question and answered by students at the end of the school year, after all proposals have been made dynamic. The data obtained during the observation and reading the responses to the questionnaire were evaluated by using the technique of content analysis, three themes emerged: 1 - Group dynamics and strategy for teamwork; 2 - Group dynamics as interaction strategy; 3- The group dynamics as a strategy for teaching and learning.

Content analysis is formed by a set of analysis techniques of communication that seeks, for systematic and objective procedures to describe the content of the messages, indicators, quantitative or not, allowing the deduction of knowledge concerning the conditions of production / reception of these messages. ${ }^{6}$

\section{RESULTS AND DISCUSSION}

\section{The group dynamics as a strategy for teamwork}

In nursing, the formation of groups is evident, because all the work is done by a group formed by the nursing staff, coordinated by the nurse with a focus on implementing 
care to people in educational work, the shift report, continuing education, and often in services which coordinates the multidisciplinary team. ${ }^{7}$

Despite this reality, the nursing literature demonstrates a lack of strategies and models for the formation of cohesive working group that favors the development of therapeutic care to people in suffering, be it mental, physical or social. ${ }^{8}$

When asked about the meaning of the realization of the dynamics in the classroom, many students have noticed the dynamics showed the importance of team work and its results, as the answers below:

The group dynamics meant that the nursing work must be done in teams. (Student 1)

It was interesting to learn through a dynamic the importance of teamwork. (Student 2)

Basically values teamwork and the results that can be obtained with the same. (Student 3)

We showed that the group work well prepared and well planned triggers the realization of actions quickly, reaching the desired goals and objectives. (Student 4)

In the world of nursing course, student beginners have a view toward nursing care area and few know about the care management. This lack of knowledge is reflected in the immaturity nursing management and also for the leadership of a team, requiring, therefore, higher vocational training, which includes the study of nursing management. Be a leader and manager are features that must be worked during the training of nurses for that later, the professional can take advantage of these skills and implement them properly.

It is understood that to exercise leadership, the nurse manager must understand the differences between leading and managing and seek to develop capacity to exercise leadership. To become a leader, one of the attributes is required to work as a group, to build the organization.

Health services, as well as other organizations, have been seeking this management advances, to provide answers to the evolutionary process of contemporary society. The implementation of the NHS and its decentralization have encountered difficulties in obtaining this run, as assumed, in this model, greater autonomy and responsibility of municipalities in the management of health services. This process has collided with the lack of preparation of the teams to take on managerial roles and leadership. ${ }^{9}$

Given these results, the sooner you work these skills during the nursing program, most students prepare for a performance quality as a manager and as a leader. It is believed that the undergraduate nursing should stimulate the development of managerial and leadership skills, as the job market requires nurses such skills. ${ }^{9}$

\section{2 - Group dynamics and integration strategy}

The practice of group work has been, over time, most required in our society still marked by individualism, hierarchical relationships and competitiveness. The work group increases the possibility of more supportive relationships, to the extent that people recognize themselves in their similarities and differences, learning to build ideas and actions collectively. ${ }^{10}$ 
When starting a new discipline, there is, for the students, a curiosity and anxiety about what will be studied and also a fear about their income and their relationship with the new teacher who will be ministering class. The group dynamic also appears in this context as a measure to reduce this anxiety and facilitate student interaction with other students and the teacher.

Group work benefits the interaction among students, increasing the quality of learning and acquiring new knowledge. Moreover, improves social skills, enabling dialogue, facilitating communication and inclusion of its members. It is worth noting that the group work causes students to learn in order to help each other in their learning, ie, in a cooperative way, they become favorable to the intentions and needs of each other. ${ }^{11}$

Observed in the speech of students they recognize that enabled a dynamic environment that facilitates interaction between class members and teachers, and create a relaxed atmosphere to discuss issues, which are often seen as boring and dull:

Works as an "ice breaker" in the first class with new students and new teachers. (Student 5)

Allowing the exchange of ideas among teachers and students. (Student 6)

The dynamics allowed the students understanding of the need of interaction between people in the workplace (...) (Student 7)

Facilitates team interaction, and provide a moment of relaxation (Student 8)

To be nursing an area of constant interpersonal relationships, it is important that the student, since graduation, be aware of the importance of interacting with each other, to recognize within a particular group and from that point, seek their group identity and individual.

Group dynamics is an extremely important tool to establish better interaction and trust between teacher and student, as this interferes with learning. By using group dynamics will be the teacher providing opportunities for the creation of a climate conducive to integration, approach, resulting in greater opportunities for meaningful learning. Moreover, you can know better the student, their needs and specificities and leverage advances, based on experience already experienced. Information and hypotheses obtained after completion of dynamics can serve to Professor reevaluate its planning, according to how each student responds to certain commands and / or situations.

The professional practice of nurses is in care, management or teaching, requires the development of attributes related to team work, which involves, for example, selfawareness, listening, dialogue, living with diversity, authenticity, knowledge and experiences that allow specific understanding of the group process (the momentum that builds when people work together / group) and the possibilities of coordination / intervention, in order to generate learning situations and transformation. ${ }^{10}$

\section{3 - The dynamics of the group as a strategy for teaching and learning}

Throughout the nursing college is a great difficulty for the students to accomplish the theoretical content of the practice at the time when it is in curricular and even later when you are acting professionally. In Management discipline, there is the need for each student to identify and stimulate themselves the managerial skills and become aware of the importance and effectiveness of the same in the workplace. 
It is believed that the group dynamics, in this context, allow the student to participate in the process of teaching and learning and the educational institution is no longer just a place to practice the transmission of knowledge, to take a role in transforming attitudes. This technique of instruction in schools indicates to be a practical awareness, enabling greater involvement of participants in their learning process. Also, allows enriching experiences and experiences of group members. ${ }^{12}$

It can be argued that the great advantage of the use of group dynamics in the classroom is the opportunity to create an experience playful, exciting and motivating that to be crafted from the syllabus, breaks the traditional models of teaching, approaching it is thus a teaching model more holistic and integrated. ${ }^{13}$

In this regard, scholars responded that:

The dynamics provided a new look at what is management, emphasizing that, even as a manager, it is essential to marriage. We all need to do the job well done, to achieve good results. (Student 9)

The dynamic is important because it helps to understand the content more easily. (Student 10)

It is important to contextualize and motivate the theory. (Student 11)

The dynamics enabled me to understand various skills and administrative processes. (Student 12)

Group dynamics facilitates learning in a practical and comprehensive. (Student 13)

The dynamic was a good start of the discipline, as simplified content team spirit. (Student 14)

The daily practice of teaching in universities still signals the occurrence of an education centered on the figure of the teacher holder of knowledge. Teaching strategies are repetitive and classes are mostly expository, thus creating a flow of one-way communication. The historical and social moment we live in today demands that the professional has a profile more critical, bold and insightful. It is observed that nurses are being placed in the job market unprepared, not so much on the technical dimension, but what is more aggravating in the sense of critical thinking. ${ }^{14}$

The educator must reflect on nursing aspects designed to develop the students' critical thinking, aiming to promote leadership in nursing. The dynamic process of asking, to reason, to question, contributes to the development of thinking and should include ways to develop critical thinking as an integral part in the education of nurses, so you can directly pass on their leadership. ${ }^{15}$
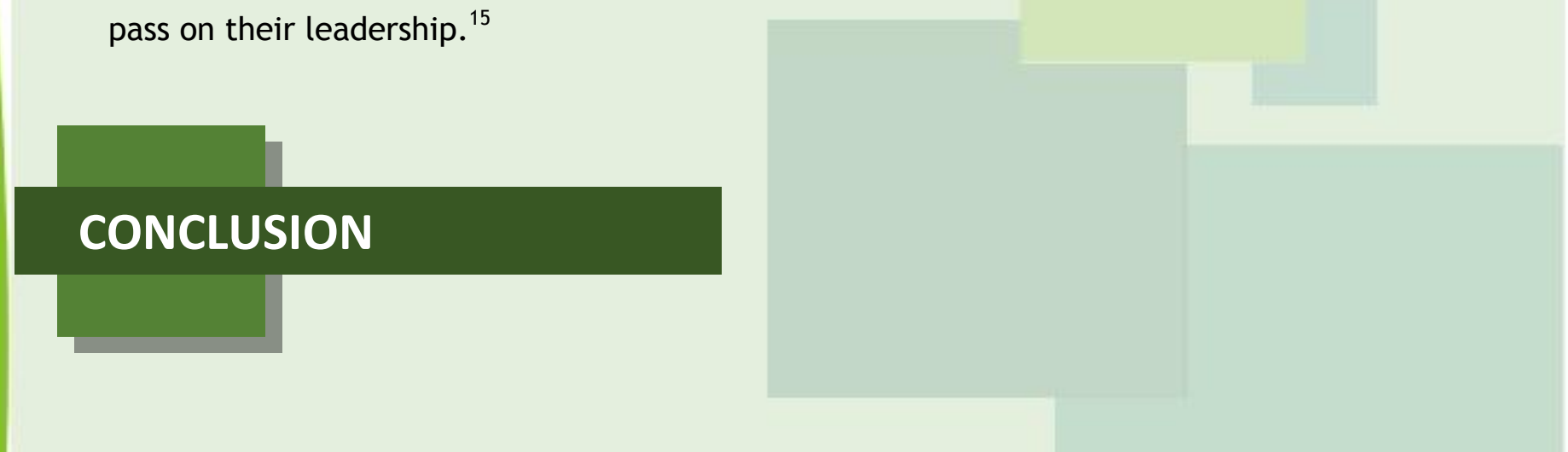

The nursing education cannot be passive, since the profession requires active individuals for a better result, or in any field. However, for this feature emerges or enhances the nursing students, there needs to be stimulated. The group dynamics are seen 
as a way to exploit this knowledge and stimulating student interaction in the group / team reflection on topics covered in class, as well as the interaction and knowledge exchange with the teacher, leaving being a "banking education" as Freire referred, where teachers "lay" an amount of knowledge in students.

By the speeches of the academics, it can be concluded that the use of dynamics as a strategy for teaching and learning, had full acceptance. The contribution of this tool translates the importance of using this method for the process of nursing education.

\section{REFERENCES}

1. Gonçalves A M, Perpétuo S C. Dinâmica de grupo na formação de lideranças. 5 ed. Rio de Janeiro: DP\&A; 2002.

2. Osório IC, Et al. Grupoterapia hoje. Porto alegre: Artes médicas; 1986.

3. Saeki T, Munari DB, Alencastre MBA, Souza MC. Reflexões sobre o ensino de dinâmica de grupo para alunos de graduação em enfermagem. Rev Esc Enferm Usp. 1999 dec; 33(4): 342-7.

4. Minayo MCS. 0 desafio do conhecimento: pesquisa qualitativa em saúde. 8 ed. São Paulo: hucitec; 2004.

5. Gil AC. Como elaborar projetos de pesquisa. 3 ed. São Paulo: Atlas; 1991.

6. Bardin L. Análise de conteúdo. 5 ed. Lisboa: Edições; 2009.

7. Fernandes CNS. O enfermeiro como coordenador de grupos: contribuições da dinâmica de grupo. Rev Eletrônica Enferm. [periódico on line] 2008; [citado 19 ago 2012]; 10(1): 257-258. Disponível em: http://www.ufg.br/conpeex/2006/porta_arquivos/posgraduacao/1451578CarlaNatalinadaSilvaFernandes.pdf.

8. Leopardi MT. Teoria e método em assistência de enfermagem. 1 ed. Florianópolis: soldasoft; 2006.

9. Lourenço MR, Shinyashik GT, Trevizan MA. Gerenciamento e liderança: análise do conhecimento dos enfermeiros gerentes. Rev Latinoam Enferm. [periódico on line] 2005 jul; [citado em 19 ago 2012]; 13(4): 469-73. Disponível em: http://www.scielo.br/pdf/rlae/v13n4/pt_v13n4a02.pdf

10. Barbato RG, Corrêa AK, Souza MCBM. Aprender em grupo: experiência de estudantes de enfermagem e implicações para a formação profissional. Esc Anna Nery Ver Enferm. [periódico on line] 2010 jan; [citado em 19 ago 2012]; 14(1): 48-55. Disponível em: http://www.scielo.br/pdf/ean/v14n1/v14n1a08.pdf

11. Bonals J. O trabalho em pequenos grupos na sala de aula. Porto Alegre: Artmed; 2003.

12. Almeida PN. O ensino globalizante em dinâmicas de grupo. São Paulo: Saraiva; 1973.

13. Bosco TC, Sudo CH. Dinâmicas de grupo como estratégia de educação ambiental: estudo de caso na educação de jovens e adultos. Congresso Brasileiro de Gestão Ambiental: Anaisdo II Congresso Brasileiro de Gestão Ambiental; 2011 nov 06-09; Londrina (PR). IBEAS; 2011. 
14. Stacciarini JMR, Esperidião E. Repensando estratégias de ensino no processo de aprendizagem. Rev latinoam enferm. [periódico on line] 1999 dez; [citado 21 ago 2012]; 7(5): 59-66. Disponível em: http://www.scielo.br/pdf/rlae/v7n5/13505.pdf

15. Isaacs IG. El efecto de enseñar las destrezas del pensamiento crítico en un curso introductorio de enfermería. Rev latinoam enferm. [periódico on line]; 1994 jan; [citado 21 ago 2012]; 2(2): 115-127. Disponível em: http://www.scielo.br/scielo.php?pid=S0104$11691994000200009 \&$ script=sci_abstract\&tlng=pt. 